\title{
KEEFEKTIFAN KONSELING KELOMPOK REALITA UNTUK MENINGKATKAN PEMAHAMAN IDENTITAS DIRI SISWA SEKOLAH MENENGAH PERTAMA
}

\author{
Maslikan \\ e-mail: maslikan234@gmail.com \\ SMK Walisongo Pacet Mojokerto \\ Jl. Mohammad Sholeh No 270, Pacet, Kab. Mojokerto
}

\begin{abstract}
Abstrak: Penelitian ini bertujuan menguji keefektifan konseling realita untuk meningkatkan pemahaman identitas diri siswa SMP. Penelitian ini menggunakan jenis penelitian pre eksperimen pretest-posttest one group design. Analisis data yang digunakan adalah uji statistik paired sampel T-test, untuk melihat perubahan tingkat pemahaman identitas diri pada kelompok eksperimen antara pre-test dan posttest dengan melihat harga $t_{\text {tabel }}$ pada derajat kebebasan $(\mathrm{dk})$, yaitu besarnya adalah $\mathrm{N}-1$, dan pada taraf signifikan $a=0,05(95 \%)$ maka didapatkan $t_{\text {tabel }}=1.771$, dengan asumsi jika $t_{\text {hitung }}>t_{\text {tabel }}$ maka $\mathrm{H}_{a}$ "diterima" dapat dimaknai konseling kelompok realita efektif untuk meningkatkan pemahaman identitas diri siswa SMP. Penelitian ini dilaksanakan mulai dari bulan April sampai dengan Juli 2018, yang bertempat di SMP Negeri 2 Mojosari. Berdasarkan temuan penelitian, disarankan sebagai berikut (1) bagi guru Bimbingan dan Konseling, konseling kelompok dapat diterapkan di sekolah secara efektif, terutama dalam meningkatkan pemahaman identitas diri siswa; (2) bagi peneliti selanjutnya, konseling kelompok realita efektif dalam meningkatkan pemahaman identitas diri siswa, hendaknya bisa menjadi inspirasi dalam melakukan penelitian selanjutnya dengan menerapkan konseling kelompok dengan teknik-teknik yang lain terutama dalam usaha meningkatkan pemahaman identitas diri siswa.
\end{abstract}

Kata-kata kunci: konseling, kelompok realita, pemahaman identitas diri

\section{EFFECTIVE GROUP COUNSELING REALITY TO IMPROVE UNDERSTANDING OF SELF-IDENTITY OF JUNIOR HIGH-SCHOOL STUDENTS}

\begin{abstract}
This study aims to test the effectiveness of reality counseling to improve students' self-identity in junior high. This research uses pre experimental with pretest-posttest one group design. The data analysis used is paired test of T-test. To see the change of self-understanding level in the experimental group between pretest and posttest by looking at the price of $t_{\text {table }}$ on the degrees of freedom (dk), ie the amount is $\mathrm{N}-1$, and at a significant level $a=$ $0.05(95 \%)$ then obtained $t_{\text {table }}=1.771$, assuming if $t_{\text {hitung }}>t_{\text {tabel }}$ then $H_{a}$ "received" the meaning of group reality counseling is effective to improve understanding of the identity of junior high-school students. The research was carried out starting from April to July 2018, which took place at SMP Negeri 2 Mojosari. Based on the findings of the study, it is suggested as follows (1) for Guidance and Counseling teachers, group counseling can be applied effectively in schools, especially in improving understanding of students' self-identities; (2) for researchers, furthermore, group reality counseling is effective in improving self-understanding students, should be able to be an inspiration in doing further research by applying group counseling with other techniques, especially in an effort to improve students' self-identity understanding.
\end{abstract}

Keywords: counseling, reality group, understanding of self-identity

\section{PENDAHULUAN}

Sekolah Menengah Pertama (SMP) merupakan pendidikan formal pada jenjang pendidikan dasar di Indonesia yang memberikan peletakan pondasi dalam menyiapkan generasi penerus bangsa agar menjadi manusia yang mampu menghadapi era kemajuan dan perkembangan (Depdiknas, 2010). Siswa SMP adalah siswa yang memasuki masa remaja dengan karakteristik ingin mendapatkan kebebasan serta pencarian identitas diri dalam kehidupannya (Sarwono, 2011). Menurut Habsy (2017a), pada saat 
individu memasuki tahapan pendidikan di sekolah menengah, maka individu memasuki masa remaja.

Tugas terpenting bagi remaja adalah mencapai identitas diri yang lebih mantap melalui pencarian dan eksplorasi terhadap diri dan lingkungan sosial (Erikson dalam Hurlock, 2001). Remaja merupakan masa perkembangan kemandirian terhadap nilainilai estetika dan isu-isu moral (Salzman dalam Yusuf, 2004). Menurut Habsy (2018a), masa remaja merupakan tahapan dari siklus kehidupan yang banyak dibahas oleh para peneliti di bidang bimbingan dan konseling dan psikologi, sebab banyak hal menarik yang dapat ditelaah. Hal ini tidak terlepas dari berbagai karakteristik khas yang menyertai pertumbuhan dan perkembangan remaja pada aspek fisik, psikologis, spiritual, intelektual, sosial, dan ekonomi. Pernyataan tersebut mengarah pada problematika tentang identitas diri yang merupakan suatu prinsip kesatuan yang membedakan diri seseorang dengan orang lain (Kartono dalam Purwanti, 2013).

Individu yang memasuki masa remaja harus memutuskan siapakah dirinya sebenarnya dan peranannya dalam kehidupan. Ketika remaja dapat menyelesaikan krisis yang muncul dari tahap perkembangan psikososial pada masa remaja yaitu identitas versus kebingungan peran. Penyelesaian terhadap krisis yang muncul tersebut merupakan tugas utama individu pada masa remaja (Papalia, Olds, \& Feldman, 2008). Menurut Brooks \& Knowles (1982), identitas diri dapat diklasifikasikan menjadi tiga komponen yaitu fisik (the perceptual component), psikologis (the conceptual component), dan sikap (the tttitudinal component). Proses pembentukan identitas diri, dapat dilihat melalui elemen-elemen pembentuk identitas diri, yaitu usaha mencari informasi dan pemahaman yang mendalam, usaha itu disebut sebagai eksplorasi (exploration); serta upaya untuk melaksanakan pilihan atas alternatif yang telah dibuat tersebut. Menurut Nurihsan (2005), sesorang yang kurang memahami identitas dirinya cenderung (1) ekspresi emosi yang berlebih-lebihan, (2) bersikap agresi, (3) memiliki perasaan frustasi , (4) mempunyai pengarahan diri yang tidak rasional, (6) tidak mampu mengembangkan kualitas dirinya, dan (7) tidak bersikap objektif.

Berdasarkan studi pendahuluan hasil observasi dan wawancara yang dilakukan pada tanggal 8 April 2018, diperoleh data mengenai problematika pada siswa SMP yang belum memahami identitas diri secara positif, gejala yang nampak yaitu membolos, hasil prestasi belajar yang rendah, membuat gaduh saat pelajaran, berkelahi, adanya siswa yang melanggar tata tertib sekolah, memiliki perasaan rendah diri, dan mempunyai perasaan tidak mampu melaksanakan tugas.

Dari hasil studi pendahuluan dapat disimpulkan bahwa siswa yang identitas dirinya rendah akan memiliki perasaan tidak berharga, tidak berarti, dan rendah diri yang berkepanjangan akibat evaluasi yang negatif terhadap diri sendiri dan kemampuan diri. Adanya perasaan hilang percaya diri, merasa gagal karena tidak mampu mencapai keinginan sesuai ideal diri. Hal ini senada dengan apa yang diungkapkan Andreouli (2010) yang mengatakan bahwa identitas diri rendah digambarkan sebagai perasaan yang negatif terhadap diri sendiri, termasuk hilangnya pemahaman identitas diri dan harga diri, serta merasa gagal mencapai keinginan, sedangkan di sisi lain, Gunarsa (2005), mengatakan identitas diri tinggi digambarkan dengan memiliki kepercayaan akan kompetensi/kemampuan diri, tidak terdorong untuk menunjukkan sikap konformis, dan mempunyai pengendalian diri yang baik.

Identitas diri adalah pandangan atau gambaran positif yang dimiliki orang tentang dirinya sebagai bentuk keyakinan yang dimiliki individu tentang diri sendiri yang meliputi karakteristik fisik, psikologis, sosial, emosional, aspirasi, dan prestasi. Identitas diri dalam penelitian ini diukur dengan menggunakan kuesioner identitas diri berdasarkan teori Brooks \& Knowles (1982) yang dapat diklafikasikan menjadi tiga komponen yaitu fisik (the perceptual component), psikologis (the conceptual component), dan sikap (the attitudinal component).

Dalam konteks bimbingan dan konseling permasalahan identitas diri termasuk dalam bidang pribadi sosial. Pada setting pendidikan upaya konselor sekolah dalam rangka membantu pencapaian standar kompetensi kemandirian siswa dengan memberikan layanan konseling. Menurut Habsy (2017b), konseling dalam lingkup pendidikan merupakan upaya penanganan masalah dalam rangka memfasilitasi perkembangan individu dalam lingkungannya yang tertuju pada upaya menciptakan kondisi optimum bagi perkembangan individu.

Salah satu pendekatan konseling yang dapat digunakan untuk membantu konseli dalam permasalahan identitas diri adalah konseling realita. Konseling realita, menurut Latipun (2008), adalah pendekatan yang didasarkan pada anggapan tentang adanya satu kebutuhan psikologis pada seluruh kehidupannya, kebutuhan akan identitas diri, yaitu kebutuhan untuk merasa unik, terpisah, dan berbeda 
dengan orang lain. Dalam proses tersebut, pendekatan konseling yang tepat untuk meningkatkan identitas diri siswa SMP adalah pendekatan konseling realita. Secara sederhana, perilaku/perbuatan tidak sesuai digambarkan sebagai individu yang kurang terlibat dengan orang lain, tidak pernah belajar untuk berbuat secara bertangung jawab, dan cenderung mengabaikan prinsip 3R yaitu Right, Responsibility, dan Reality (Wells \& Hansen, 2003).

Pendekatan konseling realita diharapkan dapat menjadi cara yang praktis guna menolong individu mengontrol hidupnya agar menjadi lebih baik (Gasser dalam Corey 2009). Lebih lanjut, Gunarsa (dalam Ristianti, 2013) menyatakan bahwa konseling kelompok dianggap potensial sebagai alternatif bantuan karena dengan adanya konseling kelompok siswa dapat belajar berpikir dan bertanggung jawab dari anggota kelompok lainnya serta tidak merasa terhakimi karena kesalahan yang dilakukan. Tujuan kelompok realita dipandang potensial untuk membantu siswa dalam memahami identitas dirinya secara positif. Menurut Corey (2009), konseling kelompok realita membantu anggota kelompok dalam memenuhi kebutuhan-kebutuhan dasar psikologisnya yang mencakup kebutuhan untuk mencintai dan dicintai serta kebutuhan untuk merasakan bahwa dirinya berguna baik bagi diri sendiri maupun bagi orang lain.

Konseling kelompok realita dalam penelitian ini adalah suatu pendekatan konseling yang dilakukan konselor dalam situasi kelompok sebagai suatu proses antar pribadi yang dinamis dan bebas yang terpusat pada pikiran dan perilaku sadar dengan melibatkan fungsi-fungsi seperti identitas, orientasi pada realita, saling mempercayai, saling pengertian, dan saling menerima dukungan. Konseling kelompok realita dirancang menggunakan terapi realita dengan model WDEP, meliputi (1) want, yaitu mengeksplorasi keinginan dan kebutuhan konseli, (2) doing, menekankan pada perilaku sekarang dan memfokuskan pada perubahan perilaku, (3) evaluation, yaitu meminta konseli mengevaluasi setiap komponen dan perilaku totalnya, dan (4) planning, yaitu meminta konseli menyusun rencana perubahan, setelah konseli menetapkan perubahan yang dikehendaki.

Berdasarkan paparan teori tersebut peneliti menyimpulkan bahwa konseling kelompok realita, merupakan intervensi yang aplikatif untuk mengatasi permasalahan-permasalahan psikologis yang meliputi peka terhadap kritik, responsif terhadap pujian, bersifat hiperkritis, merasa tidak disenangi orang lain, dan bersikap pesimis terhadap kompetisi yang menjadi prediktor dalam identitas diri, maka peneliti berasumsi bahwa konseling kelompok realita efektif dalam meningkatkan pemahaman identitas diri siswa SMP. Peneliti berkeinginan untuk melakukan penelitian lebih lanjut dan kajian secara mendalam terhadap keefektifan konseling kelompok realita sebagai aternatif bantuan untuk meningkatkan pemahaman identitas diri siswa SMP.

\section{METODE PENELITIAN}

\section{Desain Penelitian}

Penelitian ini menggunakan pendekatan kuantitatif eksperimen. Menurut Sugiyono (2010), penelitian eksperimen merupakan suatu penelitian yang berusaha mencari pengaruh variabel tertentu terhadap variabel lain. Pemahaman identitas diri sebagai variabel terikat (dependent variabel) dilambangkan dengan $Y$, sedangkan konseling kelompok realita sebagai variabel bebas (independent variabel). Dalam penelitian ini, peneliti menggunakan desain one group pretest dan posttest desain. Rancangan penelitian ini dapat digambarkan dalam gambar 2 .

\section{Pretest}

Treatment

Posttest

\begin{tabular}{|lll}
\hline T1 & $X$ & T2 \\
\hline
\end{tabular}

Gambar 1. Rancangan penelitian

Keterangan:

T1 : Pretest, untuk mengukur mean pemahaman identitas diri sebelum siswa diberi konseling kelompok realita

X : Treatment yaitu konseling kelompok realita

T2 : Posttest, untuk mengukur mean pemahaman identitas diri sesudah siswa diberi konseling kelompok realita

Berdasarkan desain penelitian di atas, dapat diuraikan kegiatan pertama yang dilakukan oleh peneliti adalah melakukan pretest dengan menyebarkan kuesioner identitas diri, kemudian subjek dengan hasil inventori identitas diri rendah akan diberikan treatment (perlakuan) berupa konseling kelompok realita kemudian dari subjek identitas diri rendah dilakukan posttest dengan kuesioner identitas diri untuk melakukan pengukuran akhir. Secara visual, kerangka kerja konseling kelompok realita untuk meningkatkan pemahaman identitas diri siswa SMP, diilustrasikan dalam gambar 2 . 


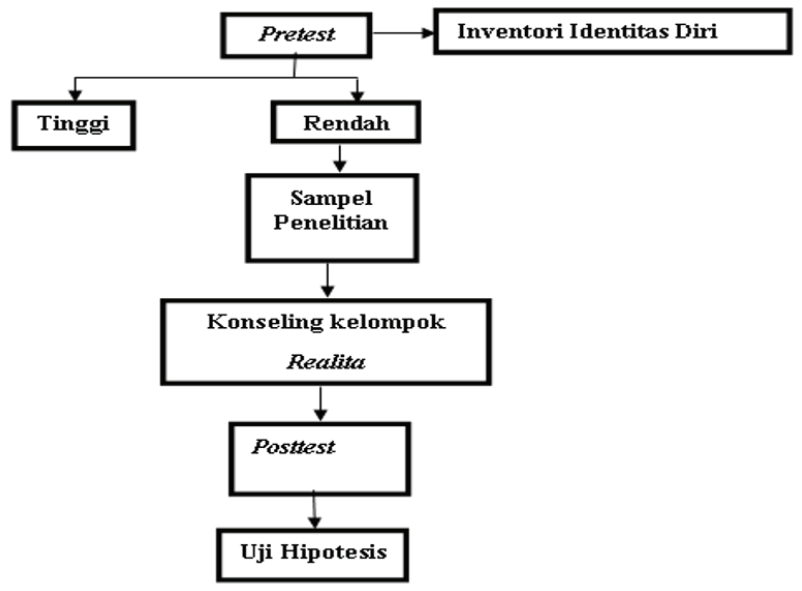

Gambar 2. Kerangka kerja penelitian (Sumber: Habsy, 2018a)

\section{Waktu Penelitian}

Penelitian ini dilaksanakan mulai dari bulan April sampai dengan Juli 2018, yang bertempat di SMP Negeri 2 Mojosari. Prosedur intervensi yang diberikan kepada sampel penelitian menggunakan konseling kelompok realita. Proses konseling dilaksanakan pada enam kali pertemuan yang masing-masing pertemuan berlangsung sekitar 45 menit. Waktu penelitian disajikan dalam tabel 1 .

Tabel 1

Prosedur dan Waktu Intervensi

\begin{tabular}{|c|c|c|c|}
\hline Pertemuan & Kegiatan & Keterangan & Waktu \\
\hline \multicolumn{4}{|l|}{ Tahap Awal } \\
\hline $\begin{array}{l}\text { Pertemuan I } \\
\text { Tanggal: } 25 \\
\text { April } 2018\end{array}$ & $\begin{array}{l}\text { Konselor menunjukkan } \\
\text { keterlibatan dengan konseli } \\
\text { (be friend) } \\
\text { (a) berkenalan } \\
\text { (b) pembentukan rapport } \\
\text { (c) ice breaking } \\
\text { (d) menjelaskan proses } \\
\text { berlangsungnya konseling } \\
\text { (e) meminta kesediaan } \\
\text { konseli mengikuti kegiatan } \\
\text { konseling } \\
\text { (f) menetapkan tujuan } \\
\text { konseling }\end{array}$ & $\begin{array}{l}\text { Konselor bersikap } \\
\text { (a) otentik, hangat, } \\
\text { menaruh perhatian } \\
\text { pada hubungan yang } \\
\text { sedang dibangun } \\
\text { (b) perilaku attending } \\
\text { (c) bersahabat dan } \\
\text { antusias } \\
\text { (d) genuine dan tidak } \\
\text { menghakimi konseli }\end{array}$ & 45 menit \\
\hline \multicolumn{4}{|l|}{ Tahap Kegiatan } \\
\hline $\begin{array}{l}\text { Pertemuan II } \\
\text { Tanggal: } 16 \\
\text { Mei } 2018\end{array}$ & $\begin{array}{l}\text { Fokus pada perilaku sekarang } \\
\text { (tahap want) } \\
\text { (a) menanyakan masalah } \\
\text { yang dihadapi siswa di } \\
\text { sekolah berkenaan dengan } \\
\text { identitas diri } \\
\text { (b) fokus pada perilaku } \\
\text { siswa saat ini yang muncul } \\
\text { berkenaan rend ahnya } \\
\text { identitas dirinya }\end{array}$ & $\begin{array}{l}\text { (a) eksplorasi "picture } \\
\text { album" (keinginan), } \\
\text { kebutuhan, persepsi } \\
\text { (b) m e n a n y a k a n } \\
\text { keinginan konseli } \\
\text { (c) menanyakan apayang } \\
\text { bear-benar diinginkan } \\
\text { konseli }\end{array}$ & 45 menit \\
\hline $\begin{array}{l}\text { Pertemuan III } \\
\text { Tanggal: } 30 \\
\text { Mei } 2018\end{array}$ & $\begin{array}{l}\text { Mengeksplorasi total behavior } \\
\text { konseli (tahap doing and } \\
\text { direction) } \\
\text { (a) mengeksplorasi total } \\
\text { behavior konseli } \\
\text { (b) konselor menyajikan } \\
\text { video Cars'R'Us Kit }\end{array}$ & $\begin{array}{l}\text { Konselor menanyakan } \\
\text { apa yang dilakukan } \\
\text { konseli, yaitu apa yang } \\
\text { dilakukan konseli; } \\
\text { cara pandang dalam } \\
\text { konseling akar masalah } \\
\text { konseli bersumber dari } \\
\text { perilakunya bukan } \\
\text { perasaannya. }\end{array}$ & 45 menit \\
\hline $\begin{array}{l}\text { Pertemuan IV } \\
\text { Tanggal: } 06 \\
\text { Juni 2018 }\end{array}$ & $\begin{array}{l}\text { Konseli menilai diri sendiri } \\
\text { a tau evaluasi (tahap } \\
\text { evaluation) } \\
\text { (a) menilai diri sendiri, } \\
\text { dalam pertemuan ini konseli } \\
\text { menunjukkan beberapa hasil } \\
\text { diskusi dan refleksi dari } \\
\text { video motivasi }\end{array}$ & $\begin{array}{l}\text { Fungsi konselor tidak } \\
\text { untuk menilai benar } \\
\text { salah perilaku konseli, } \\
\text { tetapi membimbing } \\
\text { konseli untuk menilai } \\
\text { perilakunya saat ini }\end{array}$ & 45 menit \\
\hline
\end{tabular}

\begin{tabular}{|c|c|c|c|}
\hline Pertemuan & Kegiatan & Keterangan & Waktu \\
\hline $\begin{array}{l}\text { Pertemuan IV } \\
\text { Tanggal: } 06 \\
\text { Juni 2018 }\end{array}$ & $\begin{array}{l}\text { Konseli menilai diri sendiri } \\
\text { a tau evaluasi (tahap } \\
\text { evaluation) } \\
\text { (a) menilai diri sendiri, } \\
\text { dalam pertemuan ini konseli } \\
\text { menunjukkan beberapa hasil } \\
\text { diskusi dan refleksi dari } \\
\text { video motivasi }\end{array}$ & $\begin{array}{l}\text { Fungsi konselor tidak } \\
\text { untuk menilai benar } \\
\text { salah perilaku konseli, } \\
\text { tetapi membimbing } \\
\text { konseli untuk menilai } \\
\text { perilakunya saat ini }\end{array}$ & 45 menit \\
\hline $\begin{array}{l}\text { Pertemuan V } \\
\text { Tanggal: } 28 \\
\text { Juni 2018 }\end{array}$ & $\begin{array}{l}\text { Merencanakan tindakan yang } \\
\text { bertanggung tawab (tahap } \\
\text { planning) dan membuat } \\
\text { komitmen }\end{array}$ & $\begin{array}{l}\text { (a) rencana yang disusun } \\
\text { sifatnya spesifik dan } \\
\text { konkret } \\
\text { (b) konselor mendorong } \\
\text { k o n e l i u n t u k } \\
\text { merealisasikan rencana } \\
\text { yang telah disusunnya } \\
\text { pada saat konseling }\end{array}$ & 45 menit \\
\hline \multicolumn{4}{|c|}{ Tahap Pengakhiran } \\
\hline $\begin{array}{l}\text { Pertemuan VI } \\
\text { Tanggal: } 04 \\
\text { Juli } 2018\end{array}$ & Evaluasi dan tindak lanjut & $\begin{array}{l}\text { Konselor dan konseli } \\
\text { mengevaluasi kegiatan } \\
\text { konseling yang sudah } \\
\text { dilaksanakan }\end{array}$ & 45 menit \\
\hline
\end{tabular}

\section{Populasi Penelitian}

Populasi dalam penelitian ini adalah siswa kelas VII A, B, dan C SMP Negeri 2 Mojosari Mojokerto, tahun Pelajaran 2017-2018, yang berjumlah 98 orang. Untuk lebih jelasnya tentang populasi penelitian ini, bisa dilihat pada tabel 2 .

Tabel 2

Populasi Penelitian

\begin{tabular}{ccccc}
\hline No & Kelas & $\begin{array}{c}\text { Laki- } \\
\text { Laki }\end{array}$ & Perempuan & Jumlah \\
\hline 1 & VII-A & 16 & 16 & 32 \\
2 & VII-B & 17 & 16 & 33 \\
3 & VII-C & 19 & 14 & 33 \\
\hline & Jumlah & 52 & 46 & 98 \\
\hline
\end{tabular}

Dari populasi tersebut, dipilih beberapa siswa yang teridentifikasi identitas diri rendah yang berdasarkan hasil pengukuran inventori identitas diri. Pemilihan subjek penelitian ditentukan berdasarkan pemenuhan kriteria sebagai berikut (1) tercatat sebagai siswa SMP Negeri 2 Mojosari Mojokerto, pada tahun ajaran 2017/2018, (2) teridentifikasi sebagai siswa dengan pemahaman identitas diri tingkat rendah berdasarkan alat ukur inventori identitas diri yang digunakan dalam penelitian ini, dan (3) bersedia mengikuti seluruh kegiatan intervensi yang dilakukan peneliti dan mengisi lembar persetujuan yang disediakan oleh peneliti.

\section{Teknik Analisis Data}

\section{Penentuan kategori}

Dari hasil perhitungan validitas dan reliabilitas kuesioner identitas diri, butir kuesioner yang valid disusun kembali dan selanjutnya disebarkan di kelas VII SMP. Setiap butir pernyataan kuesioner yang dijawab oleh siswa akan dihitung perolehan skornya. Setelah diketahui perolehan skor masing-masing 
siswa, selanjutnya dilakukan penentuan kategori dentitas diri siswa.

Kategori ini kemudian dinyatakan sebagai acuan dalam pengelompokan skor individu yang dikenai skala tersebut. Penyusunan skala kategori dalam penelitian ini ditetapkan batasnya berdasarkan Standard Deviasi. Penelitian ini mengkategorisasikan subjek ke dalam 3 kategori.

Skor tinggi : Mean skor +1 SD keatas

Skor sedang : Mean-1SD sampai Mean +1SD

Skor rendah Mean -1SD ke bawah

Adapun cara penentuan Mean dan Standar Deviasi (SD), menggunakan rumus berikut.

$$
\overline{\mathbf{X}}=\frac{\sum \mathrm{X}}{\mathrm{N}} \quad S D=\sqrt{\frac{\sum(X-\bar{x})^{2}}{N}}
$$

Keterangan :

$$
\begin{aligned}
\mathrm{SD} & =\text { Standar Deviasi } \\
\mathrm{x} & =\text { Mean } \\
\mathrm{X} & =\text { Jumlah skor seluruh subjek } \\
\mathrm{N} & =\text { Jumlah subjek }
\end{aligned}
$$

\section{Analisis Data}

Setelah data-data yang dibutuhkan terkumpul maka tahap selanjutnya adalah analisis data dengan menggunakan rumus Paired Samples T-test sebagai berikut.

$$
t=\frac{\bar{M} d}{\sqrt{\frac{\sum x^{2} d}{N(N-1)}}}
$$

Keterangan:

$$
\begin{aligned}
M d= & \text { mean dari deviasi }(\mathrm{d}) \text { antara posttest dan } \\
& \text { pretest } \\
x^{2} d= & \text { perbedaan deviasi dengan mean deviasi } \\
N= & \text { banyaknya subjek } \\
d f= & \text { atau db adalah } \mathrm{N}-1
\end{aligned}
$$

Selanjutnya untuk proses analisis data yang lebih akurat dan efisien dalam perhitungannya, maka perhitungan analisis data dikerjakan dengan menggunakan program SPSS 20 for Windows.

\section{HASIL DAN PEMBAHASAN}

\section{Hasil}

Dalam penelitian ini, peneliti menggunakan jenis penelitian praeksperimen. Intervensi dilakukan oleh peneliti yang berperan sebagai konselor. Pretest diberikan di awal intervensi untuk mengetahui tingkat identitas diri rendah sebelum pemberian intervensi, dengan menyebarkan kuesioner tertutup pada responden. Kuesioner terdiri dari lima alternatif jawaban dan disebarkan kepada 98 responden, yang digunakan sebagai alat ukur dalam penelitian ini. Selanjutnya dilakukan pengkategorian responden yang mengalami pemahaman identitas diri tingkat rendah berdasarkan pengukuran. Kemudian pertemuan berikutnya responden yang mengalami pemahaman identitas diri tingkat rendah diberikan perlakuan intervensi konseling kelompok realita. Pada akhir pertemuan diadakan posttest dengan menggunakan kuesioner yang sama, namun untuk menghindari validasi internal instrumensi, peneliti melakukan pengacakan item pada saat posttest. Berikut tabel 3 merupan tabel siswa yang tergolong pemahaman identitas diri rendah berdasarkan hasil pengukuran iventori identitas diri.

Tabel 3

Hasil Pretest Pemahaman Identitas Diri Siswa yang Berkategori Rendah

\begin{tabular}{cccc}
\hline No & Responden & Skor & Kategori \\
\hline 1 & AFP & 79 & Rendah \\
2 & KI & 82 & Rendah \\
3 & SM & 88 & Rendah \\
4 & TU & 88 & Rendah \\
5 & YL & 89 & Rendah \\
6 & ABY & 89 & Rendah \\
7 & AIM & 91 & Rendah \\
8 & FHM & 92 & Rendah \\
9 & SAS & 92 & Rendah \\
10 & SN & 93 & Rendah \\
11 & AM & 93 & Rendah \\
12 & AY & 94 & Rendah \\
13 & NPH & 95 & Rendah \\
14 & YL & 97 & Rendah \\
\hline
\end{tabular}

Hasil perolehan skor pretest pemahaman identitas diri siswa rendah tersebut secara jelas dapat digambarkan dalam gambar 3.

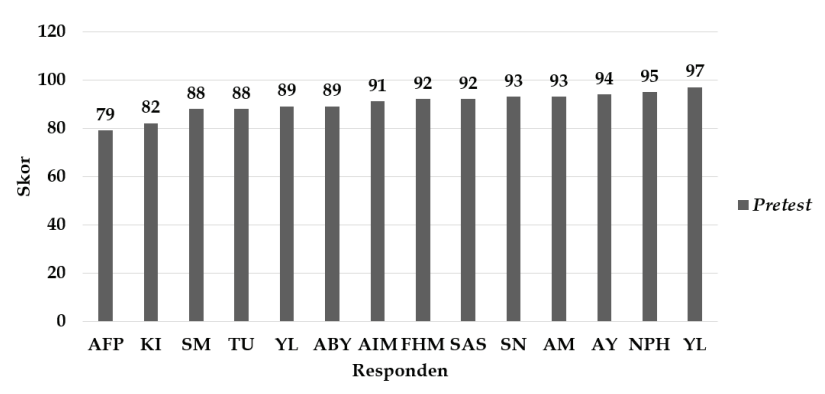

Gambar 3. Skor pretest pemahaman identitas diri siswa yang berkategori rendah 
Melihat kondisi tersebut, maka 14 siswa yang tergolong memiliki pemahaman identitas diri yang rendah diberikan konseling kelompok realita dengan harapan akan terjadi perubahan yang signifikan. Proses pemberian konseling kelompok realita ini dilakukan oleh peneliti dengan didampingi guru BK. Pada awal konseling dilakukan pretest dengan tujuan untuk mengetahui tingkat pemahaman identitas diri siswa. Pretest ini diberikan sebelum konseling kelompok realita.

Setelah diadakan pretest maka diketahui tingkat pemahaman identitas diri siswa yang rendah, kemudian diberikan konseling kelompok realita. Setelah konseling kelompok realita berakhir, maka diadakan posttest yang tujuannya untuk mengetahui tingkat pemahaman identitas diri siswa setelah diberikan konseling kelompok realita, dengan menggunakan kuesioner pemahaman identitas diri yang sama.

Kuesioner yang terdiri dari 31 pertanyaan dengan lima alternatif jawaban, disebarkan kepada 14 responden dengan kategori pemahaman identitas diri rendah setelah diberikan konseling kelompok realita. Hasil perhitungan posttest terhadap pemahaman identitas diri siswa dapat dilihat pada tabel 4 .

Tabel 4

Descriptive Statistics Posttest

\begin{tabular}{lcccccc}
\hline & $N$ & Minimum & Maximum & \multicolumn{2}{c}{ Mean } & $\begin{array}{c}\text { Std. } \\
\text { Deviation }\end{array}$ \\
\hline & Statistic & Statistic & Statistic & Statistic & $\begin{array}{c}\text { Std. } \\
\text { Error }\end{array}$ & Statistic \\
\hline Posttest & 14 & 103 & 112 & 107.14 & .837 & 3.134 \\
Missing & 0 & & & & & \\
\hline
\end{tabular}

Dari tabel 4 di atas, diketahui skor maksimal yang dicapai adalah 112 dan skor minimal adalah 103, rata-rata (mean) 107,14, dan standar deviasi adalah 3,13. Selanjutnya dilakukan kategorisasi yang digunakan untuk menentukan tingkat pemahaman identitas diri pada subjek dengan pembagian kategori sebagai berikut.

Kategori tinggi : mean skor +1 SD ke atas

$$
\begin{aligned}
& : 107,14+1(3,13)=110,27 \\
& : 110,27 \text { ke atas }
\end{aligned}
$$

Kategori sedang : mean - 1 SD sampai mean $+1 \mathrm{SD}$

$$
\begin{aligned}
: & 107,14-1(3,13) \text { sampai } 107,14+ \\
& 1(3,13) \\
: & 104 \text { sampai } 110,27
\end{aligned}
$$

Kategori rendah: mean - 1 SD ke bawah

$$
: 107,14-1(3,13)=104 \text { ke bawah }
$$$$
\text { : } 104 \text { ke bawah }
$$

Jadi, dapat disimpulkan bahwa:

Kategori pemahaman identitas diri skor tinggi $=110,27$ ke atas

Kategori pemahaman identitas diri skor sedang $=104$ sampai 110,27

Kategori pemahaman identitas diri skor rendah $=104$ ke bawah

Dengan demikian, hasil pretest pemahaman identitas diri siswa, dapat dilihat pada tabel 5 frekuensi pemahaman identitas diri posttest, sedangkan untuk hasil perolehan skor posttest pemahaman identitas setelah diberikan konseling kelompok realita secara jelas dapat digambarkan dalam gambar 4 .

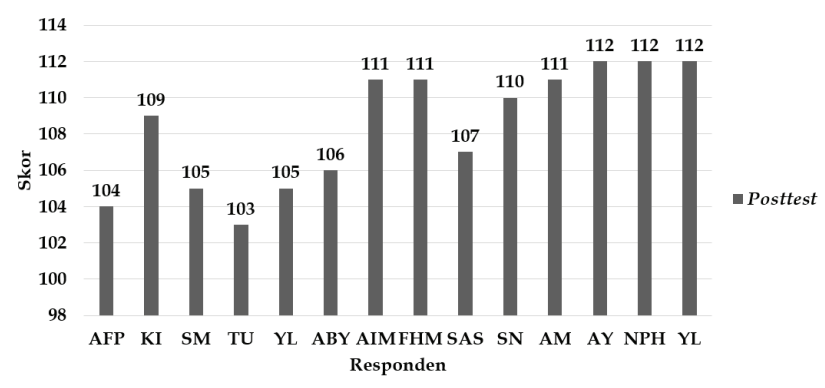

Gambar 4. Skor posttest pemahaman identitas diri siswa

Dapat disimpulkan bahwa terdapat sebanyak 14 responden yang mengalami peningkatan skor identitas diri setelah diberikan konseling kelompok realita. Berikut data keefektifan konseling kelompok realita pretest dan posttest pada 14 responden sebagai sampel penelitian.

Tabel 5

Skor Hasil Pretest-Posttest

\begin{tabular}{cccccccc}
\hline No & Konseli & Pretest & Kriteria & Posttest & Kriteria & $\begin{array}{c}\text { Arah } \\
\text { Perbedaan }\end{array}$ & Gain \\
\hline 1 & AFP & 79 & Rendah & 104 & Sedang & A1< A2 & 25 \\
2 & KI & 82 & Rendah & 109 & Sedang & A1< A2 & 27 \\
3 & SM & 88 & Rendah & 105 & Sedang & A1< A2 & 17 \\
4 & TU & 88 & Rendah & 103 & Rendah & A1< A2 & 15 \\
5 & YL & 89 & Rendah & 105 & Sedang & A1< A2 & 16 \\
6 & ABY & 89 & Rendah & 106 & Sedang & A1< A2 & 17 \\
7 & AIM & 91 & Rendah & 111 & Tinggi & A1< A2 & 20 \\
8 & FHM & 92 & Rendah & 111 & Tinggi & A1< A2 & 19 \\
9 & SAS & 92 & Rendah & 107 & Sedang & A1< A2 & 15 \\
10 & SN & 93 & Rendah & 110 & Sedang & A1< A2 & 17 \\
11 & AM & 93 & Rendah & 111 & Tinggi & A1< A2 & 18 \\
12 & AY & 94 & Rendah & 112 & Tinggi & A1< A2 & 18 \\
13 & NPH & 95 & Rendah & 112 & Tinggi & A1< A2 & 17 \\
14 & YL & 97 & Rendah & 112 & Tinggi & A1< A2 & 15 \\
\hline
\end{tabular}

Adapun kriteria pemahaman identitas diri siswa sebelum diberikan konseling kelompok realita dan pemahaman identitas diri siswa sesudah diberi konseling kelompok realita tersebut secara jelas tergambar dalam gambar 3. 


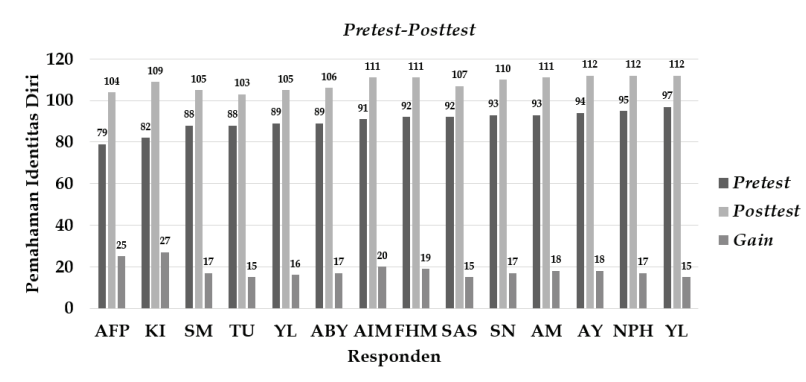

Gambar 5. Pemahaman identitas diri siswa sebelum dan sesudah diberi konseling kelompok realita

\section{Pengujian hipotesis}

Berdasarkan rumusan masalah yang diajukan, maka terdapat hipotesis yang harus diuji dalam penelitian yaitu:

$\mathrm{H}_{\mathrm{o}}$ : Konseling kelompok realita tidak efektif untuk meningkatkan pemahaman indentitas diri siswa SMP

$\mathrm{H}_{\mathrm{a}}$ : Konseling kelompok realita efektif untuk meningkatkan pemahaman indentitas diri siswa SMP

Untuk mengidentifikasi ada tidaknya konseling kelompok realita untuk meningkatkan pemahaman identitas diri SMP, peneliti menggunakan analisa data kuantitatif. Adapun rumus yang digunakan adalah rumus T-test. Selanjutnya penghitungan dilakukan dengan bantuan komputer program SPSS for Windows. T-test adalah rumus yang digunakan khusus dalam menguji hipotesis yang berisi tentang sifat dan kemampuan (traits and ability). Adapun uji t yang digunakan adalah Paired Sample T-test. Untuk melihat harga $t_{\text {tabel }}$ maka didasarkan pada derajat kebebasan (dk), yaitu besarnya adalah $\mathrm{N}-1$, yaitu 14-1=13 dan pada taraf signifikan a $=0,05(95 \%)$ maka didapatkan $t_{\text {tabel }}=1.771$, dengan asumsi jika $t_{\text {hitung }}>t_{\text {tabel }}$ maka $H_{a}$ "diterima".

Tabel 6

Paired Sample T-Test

\begin{tabular}{|c|c|c|c|c|c|c|c|c|c|}
\hline \multicolumn{10}{|c|}{ Paired Differences } \\
\hline & & \multirow[t]{2}{*}{ Mean } & \multirow{2}{*}{$\begin{array}{c}\text { Std. } \\
\text { Deviation }\end{array}$} & \multirow{2}{*}{$\begin{array}{l}\text { Std. } \\
\text { Error } \\
\text { Mean }\end{array}$} & \multicolumn{2}{|c|}{$\begin{array}{l}95 \% \text { Confidence } \\
\text { Interval of the } \\
\text { Difference }\end{array}$} & \multirow[t]{2}{*}{ t } & \multirow[t]{2}{*}{ df } & \multirow{2}{*}{$\begin{array}{c}\text { Sig. } \\
\text { (2-tailed) }\end{array}$} \\
\hline & & & & & Lower & Upper & & & \\
\hline Pair 1 & $\begin{array}{l}\text { Sesudah } \\
\text { diberi } \\
\text { konseling } \\
\text { kelompok } \\
\text { realita- } \\
\text { Sesudah } \\
\text { diberi } \\
\text { konseling } \\
\text { kelompok } \\
\text { realita }\end{array}$ & 5.8571 & 7.62443 & 2.03771 & 11.45493 & 20.2593 & 7.782 & 13 & .005 \\
\hline
\end{tabular}

Berdasarkan hasil analisis uji $\mathrm{t}$ dua sampel berpasangan pada tabel 6 , diperoleh hasil sebagai berikut nilai $t_{\text {hitung }}$ lebih besar dari $t_{\text {tabel }}(7.782>1.771)$. Nilai $t_{\text {hitung }}>t_{\text {tabel' }}$ maka hipotesis yang diajukan berupa hipotesis alternatif $\left(\mathrm{H}_{\mathrm{a}}\right)$ yang berbunyi terdapat efektivitas konseling kelompok realita untuk meningkatkan pemahaman identitas diri siswa SMP "diterima".

Selanjutnya, dari tabel 6 tersebut pula dapat diketahui bahwa nilai t bertanda positif, ini mempunyai arti bahwa variabel bebas (konseling kelompok realita) mempunyai pengaruh yang signifikan dalam memengaruhi variabel terikat (pemahaman identitas diri). Artinya, jika variabel konseling kelompok realita $(X)$ ditingkatkan maka akan berdampak untuk meningkatkan pemahaman identitas diri (Y).

\section{Pembahasan}

Dari hasil penelitian ditemukan bahwa adanya efektivitas konseling kelompok realita untuk meningkatkan pemahaman identitas diri siswa SMP. Hal ini dibuktikan dengan temuan peningkatan poin hasil pretest-posttest dari responden.

Subjek AFP, poin sebelum mendapat perlakuan adalah 79 yang termasuk dalam kategori rendah. Skor pemahaman identitas diri AFP sesudah mendapat perlakuan adalah 104 yang termasuk dalam kategori sedang, sehingga terdapat kenaikan skor pemahaman identitas diri sebanyak 25 poin.

Subjek KI, skor pemahaman identitas diri KI sebelum mendapat perlakuan adalah 82 yang termasuk dalam kategori rendah. Setelah mendapat perlakuan skor menjadi 109 yang termasuk dalam kategori sedang sehingga terdapat kenaikan skor pemahaman identitas diri sebanyak 27 poin.

Subjek SM, skor pemahaman identitas diri SM sebelum mendapat perlakuan adalah 88 yang termasuk dalam kategori rendah. Skor pemahaman identitas diri SM setelah mendapat perlakuan adalah 105 yang termasuk dalam kategori sedang. sehingga terdapat kenaikan skor pemahaman identitas diri sebanyak 17 poin.

Subjek TU, skor pemahaman identitas diri TU sebelum mendapat perlakuan adalah 88 yang termasuk dalam kategori rendah. Skor pemahaman identitas diri TU setelah mendapat perlakuan adalah 103 yang termasuk dalam masih kategori rendah mendekati sedang sehingga terdapat kenaikan skor pemahaman identitas diri sebanyak 15 poin.

Subjek YL, skor pemahaman identitas diri YL sebelum mendapat perlakuan adalah 89 yang termasuk dalam kategori rendah. Skor pemahaman identitas diri YL berubah setelah mendapat perlakuan yaitu menjadi 105 yang termasuk dalam kategori tinggi. Dengan kata lain, terdapat kenaikan skor pemahaman identitas diri sebanyak 16 poin.

Subjek ABY, skor pemahaman identitas diri ABY sebelum mendapat perlakuan adalah 89 yang termasuk dalam kategori rendah. Skor pemahaman 
identitas diri ABY setelah mendapat perlakuan adalah 106 yang termasuk dalam kategori sedang. Terdapat kenaikan skor pemahaman identitas diri sebanyak 17 poin.

Subjek AIM, skor pemahaman identitas diri AIM sebelum mendapat perlakuan adalah 91 yang termasuk dalam kategori rendah. Skor pemahaman identitas diri AIM setelah mendapat perlakuan berubah menjadi 111 yang termasuk dalam kategori tinggi. Dengan kata lain, terdapat kenaikan skor pemahaman identitas diri pada AIM sebanyak 20 poin.

Subjek FHM, skor pemahaman identitas diri FHM sebelum mendapat perlakuan adalah 92 yang termasuk dalam kategori rendah. Skor pemahaman identitas diri FHM setelah mendapat perlakuan adalah 111 yang termasuk dalam kategori tinggi. Terdapat kenaikan skor pemahaman identitas diri sebanyak 19 poin.

Subjek SAS, skor pemahaman identitas diri SAS sebelum mendapat perlakuan adalah 92 yang termasuk dalam kategori rendah. Skor pemahaman identitas diri ABY setelah mendapat perlakuan menjadi 107 yang termasuk dalam kategori sedang. Hal tersebut menunjukkan terdapat kenaikan skor pemahaman identitas diri sebanyak 15 poin.

Subjek SN, skor pemahaman identitas diri SN sebelum mendapat perlakuan adalah 93 yang termasuk dalam kategori rendah. Skor pemahaman identitas diri SN setelah mendapat perlakuan adalah 110 yang termasuk dalam kategori sedang. Dengan demikian, terdapat kenaikan skor pemahaman identitas diri terhadap SN sebanyak 17 poin.

Subjek AM, skor pemahaman identitas diri AM sebelum mendapat perlakuan adalah 93 yang termasuk dalam kategori rendah. Skor pemahaman identitas diri AM berubah setelah mendapat perlakuan menjadi 111 yang termasuk dalam kategori tinggi. Terdapat kenaikan skor pemahaman identitas diri sebanyak 18 poin.

Subjek AY,skor pemahaman identitas diri AY sebelum mendapat perlakuan adalah sebesar 94 yang termasuk dalam kategori rendah. Skor pemahaman identitas diri AY setelah mendapat perlakuan adalah 112 yang termasuk dalam kategori tinggi. Terdapat kenaikan skor pemahaman identitas diri sebanyak 18 poin.

Subjek NPH, skor pemahaman identitas diri ABY sebelum mendapat perlakuan adalah 89 yang termasuk dalam kategori rendah. Skor pemahaman identitas diri ABY sesudah mendapat perlakuan adalah 105 yang termasuk dalam kategori tinggi. Terdapat kenaikan skor pemahaman identitas diri sebanyak 16 poin.

Subjek YL, skor pemahaman identitas diri YL sebelum mendapat perlakuan adalah sebesar 97 yang termasuk dalam kategori rendah. Skor pemahaman identitas diri YL berubah menjadi 112 setelah mendapat perlakuan dan termasuk dalam kategori tinggi. Dengan kata lain, terdapat kenaikan skor pemahaman identitas diri sebanyak 15 poin.

\section{PENUTUP}

\section{Kesimpulan}

Berdasarkan hasil pembahasan dalam penelitian ini, maka dapat disimpulkan sebagai berikut (1) peningkatan hasil skor inventori identitas diri pada siswa SMP sesudah pemberian konseling kelompok realita, dan (2) pelaksanaan konseling kelompok realita efektif dalam meningkatkan pemahaman identitas diri siswa SMP.

\section{Saran}

Berdasarkan simpulan hasil penelitian diajukan saran sebagai berikut (1) bagi guru Bimbingan dan Konseling. Hasil temuan dalam penelitian ini menunjukkan bahwa konseling kelompok realita efektif dalam meningkatkan pemahaman identitas diri siswa, maka konseling kelompok realita dapat diterapkan oleh para guru BK/konselor di sekolah, terutama dalam meningkatkan pemahaman identitas diri siswa, dan (2) bagi peneliti selanjutnya. Dengan adanya, temuan bahwa pelaksanaan konseling kelompok realita efektif dalam meningkatkan pemahaman identitas diri siswa, hendaknya dapat menjadi inspirasi dalam melakukan penelitian selanjutnya dengan menerapkan konseling kelompok dengan teknik-teknik yang relevan, terutama dalam usaha meningkatkan pemahaman identitas diri siswa.

\section{DAFTAR PUSTAKA}

Andreouli, E. (2010). Identity, positioning and self-other relations. Papers on Social Representations, 19(1), 14-1.

Azwar, A., \& Prihartono, J. (2003). Metodologi penelitian kedokteran dan kesehatan masyarakat. Batam: Binarupa Akara.

Brooks, M., \& Knowles, D. (1982). Parents' views of children's imaginary companions. Child Welfare, 61(1). 25-33.

Corey, G. (2009). Theory and practice of counseling and psychotherapy. Belmont, CA: Brooks.

Depdiknas. (2010). Buku pedoman sertifikasi pendidik untuk dosen tahun 2010: Buku I naskah akademik. 
Direktorat Jenderal Pendidikan Tinggi.

Gunarsa, S. D. (2005). Psikologi perkembangan anak dan remaja. Jakarta: Gunung Mulia.

Habsy, B. A. (2017a). Model konseling kelompok cognitive behavior untuk meningkatkan self esteem siswa SMK. Perspektif Ilmu Pendidikan, 31(1), 21-35. doi: https:/ / doi.org/10.21009/PIP.311.4

Habsy, B. A. (2017b). Filosofi ilmu bimbingan dan konseling Indonesia. Jurnal Pendidikan (Teori dan Praktik), 2(1), 1-11. doi: http://dx.doi. org/10.26740/jp.v2n1.p1-11

Habsy, B. A. (2018a). Konseling rasional emotif perilaku: Sebuah tinjauan filosofis. Indonesian Journal of Educational Counseling, 2(1), 13-30. doi: https://doi.org/10.30653/001.201821.25

Habsy, B. A. (2018b). Model bimbingan kelompok PPPM untuk mengembangkan pikiran rasional korban bullying siswa SMK Etnis Jawa. Jurnal Pendidikan (Teori dan Praktik), 2(2), 91-99. doi: http:/ / dx.doi.org/10.26740/jp.v2n2.p91-99

Hurlock, E. B. (2001). Developmental psychology. New York: Tata McGraw-Hill Education.

Heriyadi, A. (2013). Meningkatkan penerimaan diri (self acceptance) siswa kelas VIII melalui konseling realita di SMP Negeri 1 Bantarbolang Kabupaten Pemalang tahun ajaran 2012/2013. Disertasi. Semarang: Universitas Negeri Semarang.

Latipun. (2008). Psikologi konseling. Malang: UPT Penerbitan Universitas Muhammadiyah Malang.
Masrohan, A. (2014). Penerapan konseling kelompok realita teknik WDEP untuk meningkatkan disiplin belajar siswa kelas XI IPS SMA Negeri 1 Rogojampi Banyuwangi. Jurnal BK UNESA, 4(3). 1-10. http:/ /jurnalmahasiswa.unesa.ac.id/ index.php/jurnal-bk-unesa/article/view/9046

Nurihsan, A. J. (2005). Strategi layanan bimbingan dan konseling. Bandung: Refika Aditama.

Papalia, D. E., Olds, S.W., \& Feldman, R.D. (2008). Psikologi perkembangan. Jakarta: Kencana.

Purwanti, F. (2013). Identitas diri remaja pada siswa kelas XI SMA Negeri 2 Pemalang ditinjau dari jenis kelamin. Skripsi. Semarang: Universitas Negeri Semarang.

Ristianti, A. (2012). Hubungan antara dukungan sosial teman sebaya dengan identitas diri pada remaja di SMA Pusaka 1 Jakarta. Skripsi. Jakarta: Universitas Gunadarma.

Sarwono, S. W. (2011). Psikologi remaja. Depok: PT. Rajagrafindo Persada.

Sugiyono, P. (2010). Metode penelitian kuantitatif, kualitatif, dan RED. Bandung: CV Alfabeta.

Wells, G. B., \& Hansen, N. D. (2003). Lesbian shame: Its relationship to identity integration and attachment. Journal of Homosexuality, 45(1), 93110. doi: http:/ / psycnet.apa.org/doi/10.1300/ J082v45n01_05

Yusuf LN, Syamsu. (2004). Psikologi perkembangan anak $\mathcal{E}$ remaja. Bandung: PT Remaja Rosdakarya. 